\title{
PROBABILITY STUDY OF AN AIRPLANE CRASH ON THE KARTINI REACTOR SITE AREA
}

\author{
Zulfikar Erlan Bhagaskara $^{1 *}$, N N Aufanni ${ }^{1}$ \\ 1) Centre for Accelerator Science \& Technology, \\ National Nuclear Energy Agency, Yogyakarta \\ *Corresponding author: Zulfikar.elran@batan.go.id
}

\begin{abstract}
ABSTRAK
STUDI PROBABILITAS KECELAKAAN PESAWAT DI AREA REAKTOR KARTINI. Studi probabilitas kecelakaan pesawat di lokasi reaktor kartini telah dilakukan. Tujuan dari penelitian ini adalah untuk menentukan kemungkinan kecelakaan pesawat yang datang dari bandara di sekitar lokasi Reaktor Kartini ke Situs Reaktor Kartini. Penelitian ini dilakukan dalam beberapa tahap, yaitu identifikasi bandara di sekitar lokasi Reaktor Kartini, penyaringan awal menggunakan nilai SDV (10 km untuk bandara kecil dan 16 $\mathrm{km}$ untuk bandara besar), perhitungan probabilitas kecelakaan pesawat di lokasi Reaktor Kartini, dan membandingkan perhitungan hasil dengan peraturan yang berlaku. Berdasarkan hasil identifikasi terdapat empat bandara atau landasan pacu di sekitar lokasi Reaktor Kartini, yaitu Bandara Adi Sutjipto, Bandara Adi Sumarmo, Runway Depok, dan Bandara Internasional Yogyakarta dengan kisaran jarak dari bandara ke lokasi antara 2,26-48,23 km. Setelah penyaringan menggunakan nilai SDV, yang diketahui hanya Bandara Adi Sutjipto yang berada di dalam jari-jari SDV Reaktor Kartini, sehingga probabilitas kecelakaan pesawat dari Bandara Adi Sutjipto dihitung, yaitu 3.769 $\times 10^{-8}$ kejadian/tahun. Nilai tersebut masih di bawah ketentuan dalam Peraturan BAPETEN No. 4 tahun 2018 yaitu maksimum $10^{-7}$ kejadian/tahun, sehingga disimpulkan bahwa Reaktor Kartini aman dari kemungkinan kecelakaan pesawat.
\end{abstract}

Kata kunci: kecelakaan pesawat, probabilitas, reaktor kartini

\section{ABSTRACT}

PROBABILITY STUDY OF AN AEROPLANE CRASH ON THE KARTINI REACTOR SITE AREA. The probability study of an airplane crash at the Kartini Reactor site has carried out. The study objective is to determine the probability of an airplane crash coming from airports around the Kartini Reactor site to the Kartini Reactor Site. This study carried out in several steps, namely identification of airports around the Kartini Reactor site, initial screening using SDV values $(10 \mathrm{~km}$ for the small airport and $16 \mathrm{~km}$ for the large airport), probability calculation of airplane crash at Kartini Reactor site and comparing the calculation result with applicable regulations. Based on the identification results, there are four airports or runways around the Kartini Reactor site, they are Adi Sutjipto Airport, Adi Sumarmo Airport, Depok Runway, and Yogyakarta International Airport where the distance from the airport to the place between 2.26 - $48.23 \mathrm{~km}$. After screening using SDV value, only Adi Sutjipto Airport is inside the SDV radius of Kartini Reactor, so the probability of airplane crash from Adi Sutjipto Airport calculated about 3,769 $10^{-8}$ events/year is. This value is under the provisions in BAPETEN Regulation No. 4 of 2018 about a maximum of $10^{-7}$ events/year, so it can be concluded that Kartini Reactor is safe from the possibility of an airplane crash.

Key words: airplane crash, kartini reactor, probability

\section{INTRODUCTION}

An airplane crash on a nuclear reactor site is one of the external human-induced events that must consider ensuring nuclear reactor operations work safely [1]. An airplane crash on the nuclear reactor site can cause potential hazards like aircraft collision to the nuclear reactor structures or thermal effect and excess pressure caused by burning fuel from 
the aircraft. It can damage nuclear reactor structures and causing the release of radioactive substances into the environment [3].

The potential of an airplane crash on the nuclear installation site could be due to the site location is near the airport or airport flight corridor, and also could be due to the site location is inside airplane flight lane $[3,4]$. Kartini Reactor is not too far from several airports, for example, Adi Sutjipto Airport that located only about $2.2 \mathrm{~km}$ from Kartini Reactor [5]. Because of this high potential hazard, if the airplane crash on the Kartini Reactor site, this paper is discussing the probability of airplane crash from several airports around the Kartini Reactor site into the Kartini Reactor site.

\section{Evaluation Steps of Airplane Crash Probability}

Nuclear installation site evaluation steps for human-induced event based on Indonesia National Nuclear Energy Regulatory Agency (BAPETEN) Regulation No. 4/2018:

1. Collecting data and information about potential sources.

2. Evaluating hazards from the potential source.

3. Determining basic design parameters.

In this paper, to determine the probability of airplane crash on the Kartini Reactor site, only two steps that discussed, that are collecting data and information about the potential source and evaluating hazard from the potential source. The potential sources that considered are airports around the Kartini Reactor site, and the risk from potential sources is the danger of an airplane crash on the Kartini Reactor site.

For more details, steps to determine the occurrence probability of initiating event (airplane crash) based on BAPETEN Regulation No. 4/2018 shown in Fig. 1. Screening distance value (SDV) in BAPETEN Regulation No. 4/2018 defined as the distance from the facility for screening potential hazard sources of a negligible external event [1]. In this paper, the facility referred to Kartini Reactor, and the intended external hazard source is flight activity from the airports around Kartini Reactor. BAPETEN Regulation No. 4/2018 does not determine SDV value for airports. Still, in the IAEA Safety Series NS-G3 document, there is an example of SDV that used for small airports is $10 \mathrm{~km}$, and SDV for large (international) airports is $16 \mathrm{~km}[1,4,6]$. If the distance between the airport and the site is outside that radius, then the external hazard potential from the airport does not need to be taken into account $[1,6]$.

If the airport is within the SDV radius, it is necessary to determine the probability of initiating event occurrence (airplane crash) on the reactor site. If the likelihood of initiating event occurrence is below 10-7, there is no need to do further analysis. However, if the probability of initiating event occurrence exceeds 10-7, then it is necessary to determine the likelihood of interacting event [1,6,7]. In BAPETEN Regulation No. 4/2018, interacting events defined as events or a series of related events, where its interactions with nuclear installations can reduce the safety level of the site's personnel or items essential for safety [1].

\section{Air corridor and aviation operations safety zone}

Air corridor defined as particular airspace where an airplane must always fly inside this flight path while crossing an area. Air corridor can be a navigation aid for pilots to get off track when conditions are complicated, but the pilot must still fly inside a particular air corridor. One of the air corridors in airport flight operations that used to ensure flight safety is the Aviation Operations Safety Zone (AOSZ) [4]. Indonesian Law No. 1 of 2009 concerning Aviation defines AOSZ as land area and/or waters and airspace around airports that used for flight operations to ensure flight safety [8].

AOSZ region boundaries are described more detail in Minister of Transportation Regulation No. Km 44 of 2005 and Indonesian National Standard (SNI) No. 03-7112-2005 concerning Aviation Operational Safety Areas. The outermost boundaries of AOSZ that determined in those regulations are areas below the outer horizontal surface, i.e., as far as a radius of 15,000 meters from the airport runway. The area under smooth outside surface itself in SNI 03-7112-2005 defined as a flat field around the airport for safety and efficiency of flight operations purpose when 
aircraft approaches for landing and movement landing failure $[9,10]$. after take-off or change in the event of a

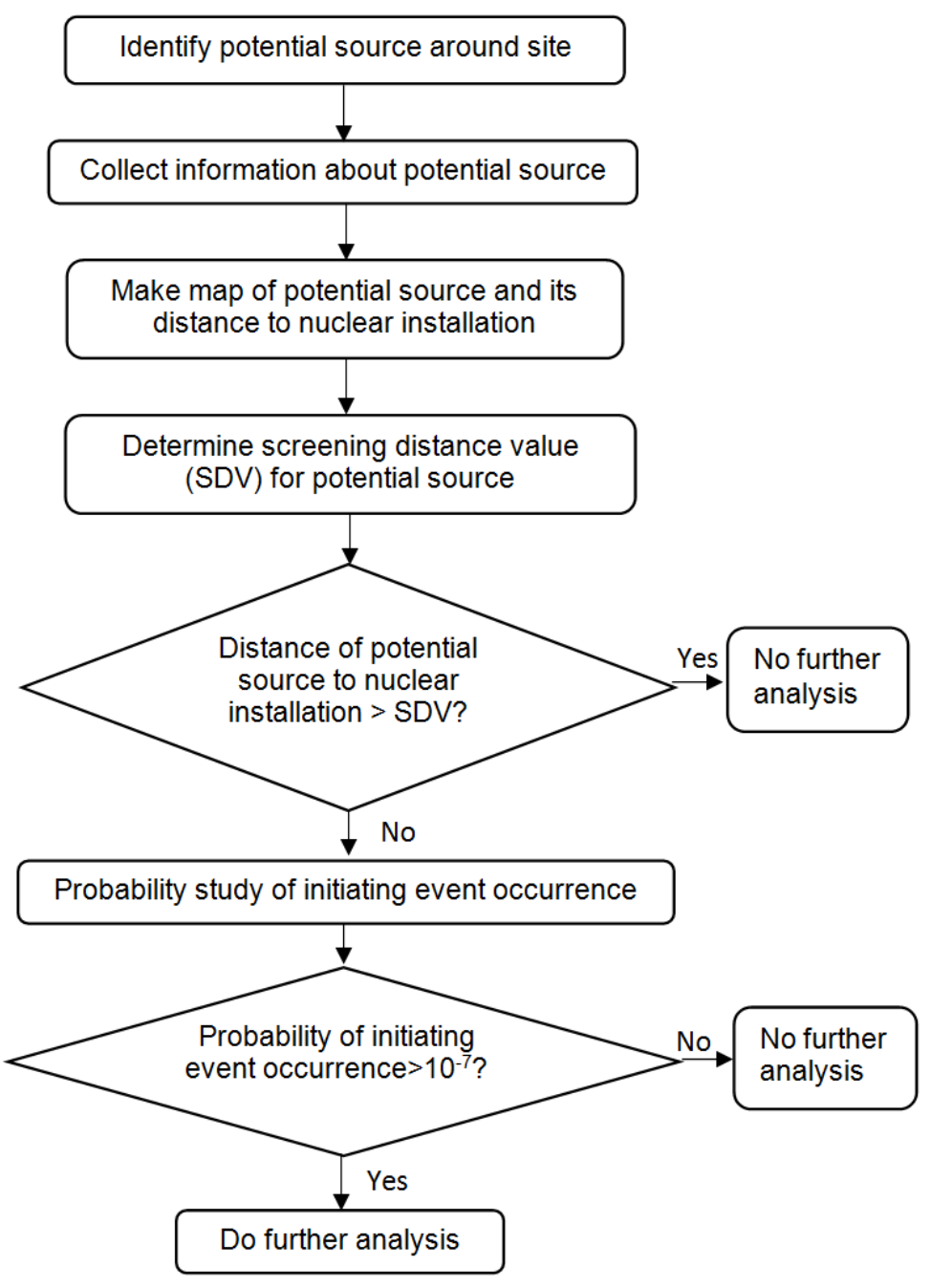

Figure 1. Flow diagram of steps to determine the occurrence probability of initiating event (airplane crash)

\section{Airplane crash possibility}

Airplane crash possibility (PFA) inside flight corridor can be calculated using Eq. 1 [4,7] with $C$ is the in-flight crash rate per mile for airplane using airway, $N$ is the number of flights per year along the airway, $A$ is active site area (square mile), and $W$ is the width of the airway or plus twice the distance from the airway edge to the site when the site is outside the airway (miles).

$$
P_{F A}=C \times N \times A / W
$$

In-flight crash rate per mile $(C)$ use plane crash rate per $\mathrm{km}$ in Indonesia about $5.4 \times 10^{-9}$ crash/plane-km or $8.7 \times 10^{-9} \mathrm{crash} /$ plane-mile [3].

\section{METHODOLOGY}

This study carried out in several steps among January-May 2019. The first is data collection. Primary data consist of site distance to the airport around the site and data of Kartini Reactor site active area. Secondary data consist of the number of flights at the airport per year and the area of airport air corridor.

The second step creates a map of the site location and the airport around the site. Then do preliminary screening based on SDV and distance between the site and the airport. The last one calculates the possibility of the 
airplane crash in the Kartini Reactor site using Eq. 1 and compares the calculation results with applicable regulations. Secondary data obtained from the Indonesian Central Statistics Agency data, and also refer to the Indonesian National Standards.

\section{RESULT AND DISCUSSION}

\section{Identification of airports around the Kartini Reactor site}

Based on the identification results, within a radius of $50 \mathrm{~km}$ from the Kartini Reactor site, there are four airports/runways around the Kartini Reactor site. They are Adi Sutjipto Airport, Adi Sumarmo Airport and Depok Runway, and Yogyakarta International Airport (YIA).

Adisutjipto Airport is located in Sleman Regency, Special Region of Yogyakarta. Now Adisutjipto Airport is used for military bases, domestic civil aviation and international civil aviation. So that Adisujipto Airport is categorized into a large airport. Then Adi Sumarmo Airport is an airport used for military bases, domestic civil aviation and international civil aviation. So that Adi Sumarmo Airport which located in Boyolali Regency, Central Java, is categorized as a large airport.

Depok runway now only is used for small aircraft flights and also used for the activities of the Indonesian Aero Sports Federation (FASI). So, Depok runway is categorized as a small airport.

The Yogyakarta International Airport (YIA) is an airport which is partly still under construction but has begun operating one flight per day. The airport is located in Kulon Progo Regency, Special Region of Yogyakarta. The airport is planned to serve domestic and international flights, so it is categorized into large airports. YIA Airport is expected to be fully operational by early 2020 [11].

\section{Airport mapping around the Kartini Reactor site and preliminary screening using SDV}

Mapping existing airports around the Kartini Reactor site based on the identification result is shown in Fig. 2.

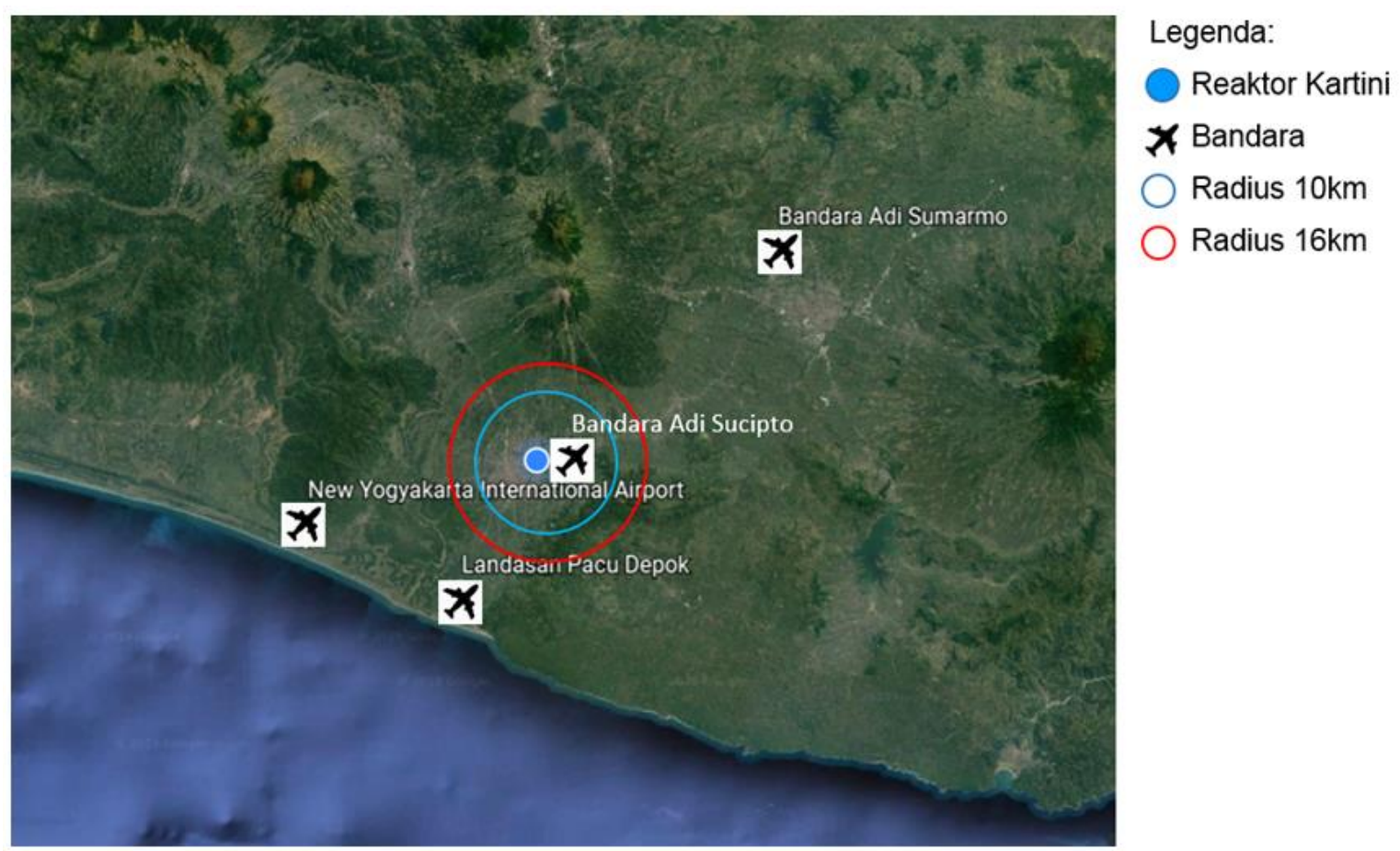

Figure 2. Map of Airport Locations Around the Kartini Reactor site

Screening distance data for each airport with SDV values are presented in Table 1. Based on the map in Fig. 2 and the screening data in Table 1, it is known that the Adi
Sutjipto Airport is within the radius of the Kartini Reactor SDV, and three other airports are outside the radius of the Kartini Reactor SDV. BAPETEN Regulation No. 4/2018 and 
IAEA Safety Guide No. NS-G-3.1, the possibility of an airplane from Adi Sutjipto Airport crash on the Kartini reactor site must be calculated. In contrast, the option of airplane crash from three other airports can be ignored.

Tabel. 1. Several airports data around the Kartini Reactor site

\begin{tabular}{cccc}
\hline Airports & $\begin{array}{c}\text { Airport } \\
\text { type }\end{array}$ & $\begin{array}{c}\text { SDV } \\
\text { Value } \\
(\mathbf{k m})\end{array}$ & $\begin{array}{c}\text { Distance to the } \\
\text { Kartini Reactor } \\
(\mathbf{k m})\end{array}$ \\
\hline $\begin{array}{c}\text { Adi Sutjipto } \\
\text { Adi Sumarmo }\end{array}$ & Large & 16 & 2.26 \\
$\begin{array}{c}\text { Depok } \\
\text { Runway } \\
\text { YIA }\end{array}$ & Small & 16 & 48.23 \\
\hline
\end{tabular}

\section{Calculation of airplane crash probability}

Probability of an airplane crash from Adi Sutjipto Airport on the Kartini Reactor site can be calculated using Eq. 1, with data that is shown in Table 2.

Tabel. 2. Data for Calculating The Airplane Crash Probability

\begin{tabular}{cc}
\hline Parameter & Value \\
\hline C : Flight accident rates per mile [3] & $8,7 \times 10^{-9}$ \\
$\mathrm{~N}:$ Number of aircraft movements & 57679 per year \\
per year [12] & \\
A : The effective area of & $3500 \mathrm{~m}^{2}=0.0014$ mile $^{2}$ \\
the Kartini reactor & $15 \mathrm{~km} \times 2=30 \mathrm{~km}=18,64$ \\
W : Airport air corridor width & mile \\
(use AOSZ) [10] &
\end{tabular}

Thus:

$$
\begin{aligned}
\mathrm{P}_{\mathrm{FA}} & =C \times N \times A W \\
& =8,7 \times 10^{-9} \times 57679 \times 0,0014 / 18.64 \\
& =3,769 \times 10^{-8} \text { events/year }
\end{aligned}
$$

From the calculation results above, it is obtained that the probability of airplane crash on the Kartini Reactor site is $3,769 \times 10^{-8}$ events/year, this value is below the limits from BAPETEN Regulation No. 4/2018, i.e. $10^{-7}$ events/year. So, it can be concluded that the Kartini Reactor is safe from the possibility of airplane crashes.

\section{CONCLUSION}

Based on the identification results, it is known that there are four airports/runways operating around the Kartini Reactor Site, they are Adi Sutjipto Airport, Adi Sumarmo Airport, Depok Runway, and Yogyakarta International Airport. However, only Adi
Sutjipto airport is within the radius of the Kartini Reactor SDV. From the calculation result, it is obtained the probability of an airplane crash at the Kartini Reactor Site is $3,769 \times 10-8$ events/year. This value is still below the limits from BAPETEN Regulation No.4/2018, i.e., $10^{-7}$ events/year. So it can be concluded that the Kartini Reactor is safe from the possibility of airplane crashes.

\section{REFERENCES}

1. National Nuclear Energy Regulatory Agency of Indonesia, "Nuclear Installation Site Safety Provisions," in BAPETEN Regulation No. 4/2018, 2018

2. International Atomic Energy Agency, "IAEA Safety Standards: Site Evaluation for Nuclear Installations," in Safety Requirement No. NS-R-3 (Rev.1), 2016

3. S.S. Nur, "Preliminary Study of the Frequency of Aircraft Fall on the Site of the NPP of the Flight Line," Proceedings of the Nuclear Safety Seminar, 2011, pp. 392-400

4. S. B. S. YARIANTO, A. SITI, and M. JUNE, "Study of Aircraft Fall in the Area of Experimental Power Reactor (RDE) PUSPITEK Serpong," Journal of Nuclear Energy Development, vol. 18(2), pp. 67-73, 2016

5. National Nuclear Energy Agency of Indonesia, "Kartini Reactor Safety Analysis Report revision 8", 2017

6. International Atomic Energy Agency, "IAEA Safety Guide: External Human Induced Events in Site Evaluation for Nuclear Power Plants," in Safety Guide No. NS-G-3.1, 2002

7. United States Nuclear Regulatory Commission "U.S. Nuclear Regulatory Commission Standard Review Plan," in Aircraft Hazard NUREG-0800 Rev.4, 2010

8. Indonesian government, Laws of the Republic Indonesia Number 1 of 2009 about Aviation, DPR RI, 2009

9. M.H. Rajasa, Regulation of the Minister of Transportation Number Km 44 of 2005 regarding Enforcement of Indonesian National Standards 03-7112-2005 about Aviation Operational Safety Areas as a Mandatory Standard, Minister of Transportation of the Republic of Indonesia, 2005 
10. National Standardization Agency, Indonesian National Standards 03-71122005 about Aviation Operational Safety Zone, National Standardization Agency, 2005

11. S. Deny, (5 May 2019). Bandara Baru Yogyakarta Beroperasi, Bagaimana Nasib
Adisutjipto? Available: https://www.liputan6.com/bisnis/read/3959168/bandarabaru-yogyakarta-beroperasi-bagaimananasib-adisutjipto

12. BPS-Statistics Indonesia, Air Transportation Statistics of 2017, BPSStatistics Indonesia, 2018 